HOW

Volume 29, Number 1, pages 9 - 36

https://doi.org/10.19183/how.29.1.595

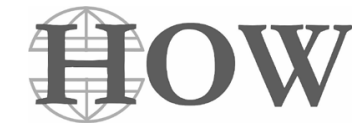

\title{
Learning Needs of English and French Students from a Modern Languages Program at a Colombian University
}

\author{
Necesidades de Aprendizaje de Inglés y Francés \\ de Estudiantes en el Programa de Lenguas Modernas \\ en una Universidad Colombiana
}

\author{
Carmelina Encarnación Mosquera ${ }^{1}$ \\ Universidad del Cauca, Popayán, Colombia
}

\begin{abstract}
This research study aims to analyze the learning needs of modern languages students at Universidad del Cauca and their implications on the bachelor's program. These needs were analyzed by exploring students' learning strategies and expectations, standards of competences, and other factors that might be affecting the learning of English and French. Data were gathered through questionnaires and a documentary review, framed by a mixed approach. The population was composed of 108 students, enrolled at the time the research started, who volunteered to take part in the study. The results show that students' needs are mainly related to developing autonomy and a sense of ownership as to learning, identifying, and using learning strategies, being trained in learning strategies use, being exposed to innovative methodologies, and being exposed to more language practice. Consequently, the modern languages program is expected to take important actions to meet students' needs in which all parties involved are committed. Finally, since needs analysis is meant to be the starting point in all teaching and learning processes, the methodology developed in this research could be useful for further studies on the same topic.
\end{abstract}

Keywords: competences, English learning, French learning, learning needs, standards, strategies

She has been teaching modern languages for more than 20 years at Cauca University. Her interests in research have been mainly on foreign languages learning and teaching, and on students' perceptions of language teaching in Cauca region. Another article derived from research is under evaluation, and it is on graduates' teaching experiences. This paper presents the final results of a research project with Code Number 5073 sponsored by Universidad del Cauca.

cmosquer@unicauca.edu.co

ORCID ID: https://orcid.org/0000-0003-3906-6587

Received: July 10th, 2020. Accepted: November 2nd, 2021.

This article is licensed under a Creative Commons Attribution-Non-Commercial-No-Derivatives 4.0 International License. License Deed can be consulted at https://creativecommons.org/licenses/by-nc-nd/4.0. 


\section{Resumen}

Esta investigación tiene como objetivo analizar las necesidades de aprendizaje de los estudiantes de Lenguas Modernas de la Universidad del Cauca y sus implicaciones en el programa de licenciatura. Estas necesidades se analizaron explorando las estrategias de aprendizaje de los estudiantes, las expectativas, los estándares de competencias y otros factores que podrían estar afectando el aprendizaje del inglés y el francés. Los datos se recopilaron por medio de cuestionarios y una revisión documental, enmarcados por un enfoque mixto. La población participante fue de 108 estudiantes matriculados en el momento en que comenzó la investigación, quienes se ofrecieron como voluntarios para participar en el estudio. Los resultados muestran que las necesidades de los estudiantes se relacionan principalmente con el desarrollo de la autonomía y el sentido de propiedad del aprendizaje, la identificación y el uso de estrategias de aprendizaje, la formación en el uso de estrategias de aprendizaje, la exposición a metodologías innovadoras y una mayor práctica del idioma. En consecuencia, se espera que el programa de Lenguas Modernas tome acciones importantes para satisfacer las necesidades de los estudiantes en las que todas las partes involucradas se comprometan. Finalmente, dado que el análisis de necesidades debe ser el punto de partida en todos los procesos de enseñanza y aprendizaje, la metodología desarrollada en esta investigación podría ser útil para futuros estudios sobre el mismo tema.

Palabras clave: aprendizaje del francés, aprendizaje del inglés, competencias, estándares, estrategias, necesidades de aprendizaje

\section{Introduction}

The University of Cauca is a public higher education institution located in the southwest of Colombia. It accommodates around 12,500 students yearly in different programs aimed to contribute to the social and cultural development of the region. One of the programs offered is the bachelor's program in modern languages with emphases on English and French, which has gone through two high quality accreditation processes, evidencing the accomplishment of the mission to promote students' professional, social, and human development.

Once the last self-evaluation process had been carried out for high-quality accreditation purposes and given the institution's being aware of the importance of inquiring about students' learning needs in English and French to implement action plans inside the modern languages program and thus, respond to English and French learning in the region, a proposal to diagnose those needs and analyze their implications in the training process 10 emerged as one of the actions contemplated in the improvement plan of the program. For this, students' learning needs were identified by analyzing factors that have influenced the process, by identifying their learning strategies and expectations, and by analyzing their language competences based on the guidelines of the Common European Framework of References for Languages.

The research methodology of the current study was grounded on a qualitative and a quantitative approach. Three questionnaires and a documentary analysis were used to collect 
data from students. Also, documentary records derived from evaluation processes carried out inside the program were revised.

The theories that were reviewed for a better understanding and to support the study were related to foreign language learning, foreign language teaching in Colombia, learning needs, learning strategies, and standards of competences.

According to the research, the most common learning needs that emerged from the findings were developing autonomy, a sense of ownership of learning, instruction in the use of learning strategies, methodologies that allow meaningful learning, and real language practice atmospheres. Taking into account these identified learning needs, some strategies are proposed for the program, which could help improve students' learning.

\section{Literature Review}

\section{Foreign Language Learning (L2)}

According to Dornyei (2001), learning a foreign language involves the learning target, the learner, and the learning environment, which may contain different factors such as the learner's motivation, language level, the target culture, and target community, among other aspects. As for Lightbown and Spada (1999), factors affecting learning are all related to personality among which are intelligence, aptitude, personality, attitude, preferences, beliefs, and age, apart from motivation. However, when measured, intelligence addresses various tasks, and for languages, IQ tests regularly stress listening, writing, and reading skills rather than students' performance in classroom interaction activities and oral communication.

As for Brown (2007), language learning comprises factors that somehow influence learners' sociocultural and educational background, life experiences and their effects on learning, abilities, strengths, and weaknesses, and their personality. In a country like Colombia, although English and French are learned as foreign languages, intercultural differences and similarities between the mother tongue and the target language also influence learning.

\section{Foreign Language Teaching in Colombia}

The General Education Law of 1994 in articles 21, 22, 23, and 31 establishes as an objective the learning of a foreign language that allows learners, from primary school onward, to develop skills to speak, read, understand, and express themselves, as foreign languages are mandatory areas of the curriculum. In accordance with this law, the Colombian Ministry of National Education creates a series of conditions that promote foreign language learning with the support of international entities and national educational institutions through projects such as COFE (Colombian Framework for English, 1995), and the National 
Bilingualism Program (PNB) 2004-2019. From 2004 to 2010, standards for the development of competences in foreign languages were adapted from the Common European Framework of Reference (2001).

From 2010 to 2014, through the "Programa de Fortalecimiento para el Desarrollo de Competencias en Lenguas Extranjeras" (PFDCLE) [Program for Strengthening the Development of Foreign Language Competences], the Ministry of Education sought to diagnose the language level and drew up training programs to strengthen English skills of both teachers and students in different regions of Colombia and, in turn, supported programs to improve teaching methodologies. Currently, the National Bilingual Program (2018-2022) seeks to strengthen pedagogical practices, promote innovating learning environments, implement learning and teaching syllabi and tools, and promote bilingual contexts.

With respect to French, Arismendi and Colorado (2015) point out that French as a foreign language in Colombia has been maintained mainly at the university level by training teachers and a diverse public interested in tourism and employment through agreements with francophone and academic companies. Regarding undergraduate programs specifically, they point out that French is taught in undergraduate languages programs in 15 universities in Colombia, complying with the levels stipulated by the Common European Framework of Reference for Languages, requiring a B2 level by 2015. According to De Mejía (2006, as cited in Arismendi \& Colorado, 2015), the integration of foreign languages in the school curriculum has been a tradition in Colombia; however, in recent decades, more emphasis has been placed on English.

According to Pérez (2018), Colombian's French learning needs are not only related to tourism but also to academic, professional, labor, and business fields, as well as to responding to the challenges of globalization and learning sociolinguistic competences. Although more emphasis has been placed on English learning in educational institutions, there is an interest in doing masters' studies in a French-speaking country, so this need is mainly met in language centers, alliances, and undergraduate training programs. Since French had occupied no place in the curricula of the Colombian educational system since the 1980s, the French Embassy in Colombia and the Ministry of National Education signed a cooperation agreement to promote French teaching in public schools in 2009.

Although the concept of foreign language and that of a second language differ from each other, the expectations that the Ministry of National Education has through the National Bilingual Program focus on the development of communicative competences, seen from a panorama suited to a second language learning context rather than to a foreign language learning context, because of the implications it entails such as the need to communicate, the learning conditions, and the input hours, among other aspects, in order to reach the expected standards. According to Sanchez and Obando (2008), the national Bilingual Program in 
Colombia was based on standards from a European context whose characteristics are not like the Colombian contexts, and whose Framework pursues different purposes. Regarding a second language, Oxford (2003) argues that it is one studied in a context in which that language is used to communicate; therefore, whoever learns it is exposed to a lot of input in that language. By contrast, a foreign language is one that is learned in a context where the target language is not primarily used to communicate, and the input is restricted. Bilingual programs implemented in other countries are successful because these are developed with contents appropriately selected, a wide range of authentic materials, and exposure to the language necessary for the achievement of the expected goals. Besides, learners' motivation towards the target language and how they can get ahead personally and professionally if they are proficient are worth mentioning (Sanchez \& Obando, 2008).

Usma (2009) states that the policies on bilingualism in Colombia have been the result of political, economic, and cultural processes associated with what is known as "globalization". However, when these policies are introduced into the school system, they reflect a disconnection from the educational realities of the country, for they are aligned with "international economic and political agendas" (De Mejía, 2004, as cited in Usma, 2009). Likewise, Gómez (2017) highlights that regarding the National Bilingual Program, there is a mismatch between Colombian realities and the actions taken and its real purpose of attending to the "workforce rather than to the need to foster social development" (p. 149).

Regarding the English levels achieved in Colombia and the statistics of the population that learns it, the British Council (2015) found that $4.1 \%$ of the population speaks English having learned it both in formal public and private education at all school levels, and through private courses and self-taught learning. This study also reveals that only $7 \%$ of Colombian students who graduated from eleventh grade reach an English level of at least A1 (beginner); students with the highest proficiency level graduate from schools in high-income areas.

According to these statistics, the achievements are not encouraging since they hardly show levels to meet expectations, because there are factors to consider so that English teaching can be effective such as the lack of qualified teachers, resources, and funding, as well as the number of students per class and the non-application of standards, especially with most of the population in public education.

As for the expectations of French learners, Torres-Martínez (2009) sustains that many Colombians are attracted to emigrate to countries like Canada and France; therefore, the implementation of the DELF and DALF ${ }^{2}$ tests or completing French courses to obtain a language level certification have been in greater demand. In the case of France, it is a

DELF-Diplôme d'etudes en langue française and DALF- Diplôme approfondi de langue française are the official certifications issued by the French Ministry of National Education, according to the 6 levels of the Common European Framework 
country that attracts a lot of attention for being a center for studies in administration and international business, as well as a training center, making it a priority destination. Regarding French teaching, a shortcoming in teacher training has been diagnosed, especially in teachers' proficiency level and qualification. The author argues that as for native French teachers, they are mostly professionals in areas other than language teaching; thus, Colombian teachers of French have little chance of updating their teaching methodologies. In his study, TorresMartínez (2009) maintains that there is "a marked conceptual and pedagogical rigidity, as well as difficulties in assuming French as a language for life (and not only for reading), grounded on real sociocultural interaction through communication strategies" (p. 20).

According to Groux et al. (2003), foreign language learning bridges the gaps between human and social interests and purposes thanks to the linguistic capital made up of foreign language skills that take on significance through social exchange.

\section{Foreign Language Learning Needs and Standards}

Ravitch (1995, as cited in Cárdenas, Chávez, \& Hernández, 2015) defines standard "as a goal and the measure of progress towards that goal" (p. 69). For the Colombian context, the Ministry of National Education has adopted standards based on those of the Common European Framework of Reference for Languages (2001), in which opportunities for interaction in the target language according to real needs is not the case. The need to communicate in English or French in Colombia is subject to the conditions in which students live, where the absence of resources for input in the L2 is common, and socio-economic and conflict situations are difficult (Guerrero, 2008, as cited in Cárdenas, Chávez, \& Hernández, 2015). The Ministry of National Education also promotes French learning so that citizens can insert the country in communication processes, global economy, and cultural exchange. According to the French Embassy in Colombia, French is a "language that offers cultural, professional, and business opportunities for development"3 (El Tiempo, March 25, 2017).

The Ministry of National Education, through Resolución 18583-2017 as one of the main axes that guarantees accreditation for universities, establishes that students from language programs must be certified at C1 level by the end of their undergraduate studies. That certification can be issued either by the Saber Pro Test ${ }^{4}$ results or any other standardized test 14 listed in the Resolución 12730 de 2017.

Munby (1978, as cited in Moreno 2004) points out the importance of analyzing needs and their relationship with curricular content, learning strategies, and teaching methods.

In Spanish "[...] francés como un idioma que ofrece oportunidades de desarrollo cultural, profesional y empresarial".

The aim of the Saber Pro test is to evaluate and report on the level of skill development and general knowledge of students from university undergraduate programs. 
Besides, Hutchinson and Waters (1987, as cited in Moreno 2004) state that linguistic needs of the target situation are based on three types of needs that they call demands, wants, and deficiencies.

According to Harmer (2007), the reasons for learning a language are diverse and influence the needs to learn it; namely, English for Specific Purposes (ESP), English for Academic Purposes (EAP), and General English. Bringing the author's approach to the context of language teaching and learning in the Modern Languages Program of the University of Cauca, the institution designed the curriculum in such a way that students learn specifically for academic and general purposes as they learn to write or speak the language to communicate effectively anywhere, anytime. In this process, no matter what the learning purpose is, learner needs emerge as they are challenged by contents and methodologies which in many cases do not meet the learners' learning styles or their expectations. Hence, autonomy plays an important role since it implies the learner's sense of responsibility, which can be strengthened by using different learning strategies to deal with those challenges.

Hutchinson and Waters (1987, as cited in Mohammed \& Mohammed, 2018) differentiate between two types of needs. They call the first, "target needs," which have to do with what students are required to do in a specific situation and include "needs", "lacks", and "wants". Target needs refer to what students must experience in order to perform in the specific situation, the gaps between what they know and should know in that situation and what they feel they need. The second type corresponds to "learning needs", which have to do with how students learn, the reasons why they learn, the course content, and location. Learning needs would be related to the learning process itself, in which students are expected to demonstrate their gradual progress.

Berwick (1989, as cited in Mohammed \& Mohammed, 2018), sustains that learning needs refer to "the accessible difference between the present situation and a future desired one" (p. 53). Therefore, they are the gap between what the learner knows and should know when performing in the target language. The social context shapes learners' social and cognitive behavior and the actions they decide to take or not to take cannot be fully understood if the context is not considered (Vygotsky, 1978; Bourdieu, 1991; Wells, 2008, as cited in Bailey, 2017). Also, in a country like Colombia, the social system influences how learners accept or choose their foreign language learning experience (Wells, 2008, as cited in Bailey, 2017). Considering these insights, L2 learning should not be separated from the sociocultural perceptions of those who learn it, since their ways of thinking and acting in society play an important role.

According to Bandura (1997, as cited in Bailey, 2017), language learning is externally controlled in Colombia. Hence, decisions about what, how, how much, where, and why the foreign language is learned do not necessarily come from learners but from established 
policies that also determine learner's needs. This argument is based on the definition of standards for primary, secondary, and tertiary levels of education by the Ministry of National Education. Ayala and Alvarez (2005) point out the importance of taking into account the needs that learners have to achieve their goals and of understanding their context for defining appropriate methodologies. They sustain that "attention has been given to foreign models" (p. 12), because of the lack of a proposal with guidelines pertinent to the characteristics of the Colombian institutions and learners. Ramos-Holguin (2021) states that pedagogical agendas must be negotiated so that a "permanent dialogue" can be promoted in the learning process. She also highlights how relevant it is to develop a pedagogy that has been negotiated with learners and teachers, and that is pertinent to that particular context.

Although focusing on L2 learning from a sociocultural perspective could respond to learner needs, from a constructivist perspective, few educational institutions in Colombia have the resources to enable this type of learning (Bailey, 2017). As a result, analyzing learning needs is an important starting point in curriculum development since these define the organization of content, goals, purposes, and objectives.

As for teaching and its implications on learning, Robert, Rosen, and Reinhardt (2011) sustain that knowing who the leaner is becomes relevant when dealing with individual characteristics, such as identity, personality, interests, and motivation to learn. Also, they highlight the implications of the learner's prior knowledge of the target language and culture and communication needs. However, language teaching tends to privilege general characteristics rather than particular ones.

\section{Learning Strategies}

The lack of effective learning strategies is one of the biggest obstacles in L2 learning (Bedoya et al., 2015). According to Scarcella and Oxford (1992, p. 63, as cited in Oxford, 2001), learning strategies are defined as "specifications, behaviors, steps or techniques", or ways of "encouraging oneself to tackle a difficult linguistic task, used by students to improve their own learning" (p. 2). Learning strategies are very useful when managing learning if they are chosen according to the type of task or learning style. Oxford (2001) points out six types of learning strategies: cognitive, metacognitive, related to memory, compensatory, affective,

16 and social. All of them are useful in making learning easier, faster, more enjoyable, effective, self-directed, and transferable to new situations when they are related to the task, fit with learning styles, and when the learner relates them to other strategies. Additionally, when learning strategies are used, learning is permanent because they promote learner autonomy (Allwright, 1990 and Little, 1991, as cited in Oxford, 2001).

Jiménez (2018) states that autonomy "[...] implies taking control of learning or selfdirecting the process and wanting to do it" (p. 72). In that process, making decisions about 
learning ways that are effective is necessary in order to take a participative stance on the learner's part. So, autonomy can also be understood as "the ability to take charge of one's own learning. This practice involves self-determination and decision-making on different aspects of learning, such as determining objectives, monitoring the process, and evaluating performance" as well as a "capacity for objectivity, critical reflection, decision-making and independent action" (Holec, 1981, and Little, 1991, as cited in Jimenez, 2018, p. 72).

Among the most used instruments for assessing learner learning strategies is the Strategy Inventory for Language Learning-SILL (Oxford et al., 1990). Through this survey, learners are exposed to different statements that help them realize whether or not they are using different learning strategies and which ones in oral or written activities to improve their learning. Several implications that learning styles have in $\mathrm{L} 2$ teaching relate to analyzing both learning styles and strategies in the classroom, adapting instruction on the L2 and strategies, and resorting to varied methodologies (Oxford, 2001).

Resnick (1988, as cited in Duquette, 2002) states that learners who have no prior knowledge of how to solve learning problems must learn to use the strategies as opposed to those who already have previous knowledge, who must merely activate them for they are useful in any situation. Regarding strategy instruction, Weinstein (1994, as cited in Cartier, 2000) points out that, first, students who are successful in their learning are those who use effective strategies in the activities proposed for them; second, to strengthen autonomy in the process, knowing and using learning strategies to develop different skills are important; and third, the strategies that students acquire will be useful for life, such as problem-solving strategies.

\section{Competence}

According to the Ministry of National Education competences relate to knowledge, skills, and individual characteristics by means of which people carry out actions in a given context. As for communicative competence, it involves linguistic, pragmatic, and sociolinguistic competence. The first competence refers to knowing formal aspects of the language and the ability to use them meaningfully. The second relates to the discursive and functional competence of the language. The third, sociolinguistic competence, refers to the knowledge of the social and cultural conditions of the target language (Estándares Básicos de Competencias en Lenguas Extranjeras: Inglés, 2006). According to Hymes (1972, as cited in Brown, 2007), communicative competence has to do with the competence that makes the individual capable of giving and interpreting messages and negotiating meanings with other people in specific contexts.

Canale and Swain (1980) and Canale (1983, as cited in Brown, 2007) define communicative competence from components of the linguistic system and functional aspects 
of communication. Communicative competence includes grammatical and sociolinguistic competence (Brown 2007). The Common European Framework of Reference for Languages (2001) points out that proficient users can understand a wide range of texts, recognize implicit meaning, express themselves fluently and spontaneously, use language flexibly and effectively for social, academic, and professional purposes, as well as produce clear, well-structured, detailed texts on complex subjects at the C1 level. At the C2 level, proficient users can understand easily what they hear or read, summarize information from different spoken and written sources, and express themselves spontaneously, very fluently and precisely. Considering that language graduates will be required to certify either $\mathrm{C} 1$ or $\mathrm{C} 2$ levels, it is pertinent to analyze the students' learning needs in order to help them achieve those competences.

\section{Methodology}

The mission of the Modern Languages program of the University of Cauca is to contribute to "the development of integral professionals, capable of performing in the field of foreign languages, based on their understanding of pedagogy, linguistics, sociohumanistics, and research" (Proyecto Educativo del Programa, 2017, p. 4). It has been offered for 50 years preparing around 260 students who come from different municipalities of the southwest of Colombia in all, each academic period. The student population in the program is characterized by different aspects. For instance, the students belong to mestizo, indigenous, and Afro-Colombian communities, which makes the program participants multicultural and implies different perceptions, interests, and needs of the students regarding English and French learning.

As the main objective of this research is to analyze modern languages students' learning needs and their implications in the program, the research question was stated as follows: What are the learning needs of the Modern Languages program students (Cohorts 20152 to 2019-2) of Universidad del Cauca? In view of this, a mixed-type approach was used entailing characteristics of both qualitative and quantitative approaches. According to Wallace (1998), the qualitative approach is used to describe data that cannot be counted or

18 measured objectively whereas the quantitative approach is mainly used to describe what can be counted or measured objectively.

The data collection process was carried out by reviewing documents of the Program and through questionnaires that included both closed and open questions to corroborate the findings emerging from the research.

As for the documentary review, the Educational Project of the Program (PEP, 2017) was consulted to find out aspects related to students' professional and work profiles, learning 
objectives, methodology, evaluation processes, language courses, and their correspondence with students' learning needs. Additionally, 13 teachers' course reports ${ }^{5}$ were revised using mind-maps and summarizing charts to provide a view of the most relevant aspects related to students' learning problems. The data gathered were categorized and grouped according to commonalities, which led to getting general categories that facilitated the analysis. Another document derived from self-reflection and self-evaluation processes led by the Committee of Professional Practice inside the languages program was revised and analyzed. The main aspects analyzed were the factors that might hinder students' learning. The data were grouped and categorized according to their commonalities.

In addition, three questionnaires were designed and shared online with the students, which included both open and closed questions. The first questionnaire contained six sections that inquired about the students' characterization, the learning process, learning expectations (Moreno, 2004), learning needs, and factors that have helped or hindered students' English and French learning. The data from the closed questions were analyzed taking into consideration the highest percentages obtained and making a contrast with the lowest ones. The data from open questions were categorized according to the common aspects found in the data.

The second questionnaire was based particularly on the Language Strategy Inventory format. It comprised two parts: The first part aimed to know about the use of general learning strategies for listening, vocabulary, speaking, reading, writing, and translation through multiple selection options, and open-ended questions about other strategies that the students were using. The second part was an open-ended question in which the students were asked to make suggestions for the program to help them develop their learning strategies.

The third questionnaire inquired about language standards developed by the students and thus, identify their learning needs. The first part was about the students' competences in oral and written comprehension and expression. The format was adapted from the Swiss version of the European Language Portfolio Self-Assessment Checklists (Little, D., \& Perclová, R., 2001), which contains standards divided into speaking, listening, reading, and writing skills. Two options were included to refer to what the students can or cannot do. A different questionnaire was used in each of the semesters, based on the skills students should demonstrate at a certain level (Semesters I and II an A2 level; semesters III and IV,

Teachers' course reports are a self-evaluation instrument inside the Modern Languages Program and are submitted at the end of each semester.

The questionnaires were administered to 108 students in total. Eight students in first semester, 19 in second semester, 23 in third semester, one in fourth semester, 15 in fifth semester, 24 in seventh semester, 11 in ninth semester, and seven in tenth semester. 
B1; semesters V and VII, B2; semesters IX and X, C1). The second part included two open questions on the perceptions of learning competences and the needs for developing them.

Table 1. General Structure of the Research

\begin{tabular}{|c|c|c|c|}
\hline Questions & Objectives & Participants & Instruments \\
\hline $\begin{array}{l}\text { Correspondence between } \\
\text { the curriculum and the } \\
\text { students' learning needs }\end{array}$ & $\begin{array}{l}\text { To find out about } \\
\text { students' professional } \\
\text { profile, program learning } \\
\text { objectives, methodology, } \\
\text { evaluation processes, } \\
\text { and course contents. }\end{array}$ & & $\begin{array}{l}\text { Documentary analysis } \\
\text { of the educational } \\
\text { project of the } \\
\text { Modern Languages } \\
\text { Program (PEP) }\end{array}$ \\
\hline $\begin{array}{l}\text { Factors influencing } \\
\text { students' learning }\end{array}$ & $\begin{array}{l}\text { To identify the factors } \\
\text { that might hinder } \\
\text { students' learning }\end{array}$ & & $\begin{array}{l}\text { Documentary analysis } \\
\text { of teachers' reports. } \\
\text { Survey carried out } \\
\text { by the professional } \\
\text { practice committee }\end{array}$ \\
\hline $\begin{aligned} & \text { - } \text { Characterization of } \\
& \text { the population } \\
&- \text { Studies completed } \\
&- \text { Reasons for studying } \\
& \text { modern languages } \\
&- \text { Participation in } \\
& \text { exchange programs } \\
&- \text { Certifications } \\
&- \text { Language exposure } \\
&- \text { Learning needs } \\
& \text { (specific/general) } \\
&- \text { Learning expectations } \\
&- \text { Factors helping/ } \\
& \text { hindering learning }\end{aligned}$ & $\begin{array}{l}\text { - To characterize } \\
\text { the population } \\
\text { - To describe students' } \\
\text { learning needs, } \\
\text { expectations, and } \\
\text { the factors hindering } \\
\text { students' learning }\end{array}$ & $\begin{array}{l}\text { Students from } \\
\text { all semesters }\end{array}$ & First Questionnaire \\
\hline $\begin{array}{ll}\text { - } & \text { Use of learning } \\
& \text { strategies } \\
\text { - } & \text { Interest in using } \\
& \text { learning strategies. } \\
- & \text { Disinterest in using } \\
& \text { learning strategies }\end{array}$ & $\begin{array}{l}\text { To inquire about } \\
\text { students' general } \\
\text { learning strategies }\end{array}$ & $\begin{array}{l}\text { Students from } \\
\text { all semesters }\end{array}$ & Second Questionnaire \\
\hline
\end{tabular}




\begin{tabular}{|l|l|l|l|}
\hline \multicolumn{1}{|c|}{ Questions } & \multicolumn{1}{|c|}{ Objectives } & Participants & \multicolumn{1}{|c|}{ Instruments } \\
\hline $\begin{array}{l}\text { Standards of } \\
\text { competences }\end{array}$ & $\begin{array}{l}\text { To analyze students' } \\
\text { standards of } \\
\text { competences according } \\
\text { to the CEFRL }\end{array}$ & $\begin{array}{l}\text { Students from } \\
\text { all semesters }\end{array}$ & Third Questionnaire \\
\hline
\end{tabular}

Table 1 shows in detail the purpose of the study and the action plan taken to answer all the leading questions and aspects to focus on, the objectives, the participants in each stage of the process, and the instruments used to collect the data.

\section{Data Analysis and Results}

The research question inquired about students' English and French learning needs and was approached from their learning strategies, expectations, communicative competences, and other factors influencing learning.

As for the curriculum (Educational Project of the Program), it was found that students' exposure to English and French lessons was high regarding the weekly hours (8 to 10); also, the program methodology is reflective, and self-evaluation processes are permanent. Foreign language instruction is articulated to pedagogy, socio-humanistic, linguistic, and research areas to promote students' integral development as future educators. Interaction in L2 in various fields of knowledge is promoted. Communication skills are developed according to standards set by national policies. The methodology promotes constant practice. Assessment procedures are used to diagnose student performance and to follow-up learning.

In relation to the teachers' reports, the main problems encountered regarding learning, lie in the fact that students are aware of their lack of autonomy and commitment to do independent tasks; these are factors that according to Jiménez (2018) learners are required to have control over, take charge of, and gain a sense of ownership of learning. In addition, it was found that students have difficulty with grammar, reading, and writing techniques, oral comprehension in French, and pronunciation in both languages. Heterogeneity in the English proficiency levels is also seen as a difficulty. It is worth mentioning that there is little information about students' learning strategies and if teachers provide instruction regarding them.

Other aspects mentioned in the reports are related to the Educational Project of the Program (PEP). For instance, critical thinking is promoted through the analysis of interesting topics. Reflection on learning and social problems is encouraged. Teaching methodologies are varied, students are exposed to different types of input material, individual tutorials 
are provided to address learning needs, evaluation is participatory and applied to followup students' performance in all language skills according to the course methodology, and students' work goes hand in hand with the objectives of the program.

Besides teachers' reports, in 2017 the Professional Practice Committee surveyed students from all semesters to find out about factors affecting their learning. The final document was revised by focusing on the aspects that might hinder the process and by taking into account teachers' and students' weaknesses and suggestions made to improve learning. Results show that students require comprehensible input, especially in first semesters in which L1 is occasionally used. According to Harmer (2007), one of the teacher's roles is that of being an input provider so that the language can be comprehensible to learners. In advanced semesters, the students would like to be more exposed to the foreign language in interaction activities that enhance real communication. When the Ministry of National Education defines foreign language (Estándares Básicos de Competencias en Lenguas Extranjeras: Inglés $\left.{ }^{7}, 2006\right)$, it refers to the exposure to the target language as a process that occurs in controlled periods; however, the expected results of the NBP suggest a permanent use of the foreign language to communicate, like in those contexts where the use of the language is not restricted; that is, where it is used as a second language (Oxford, 2003).

In all the semesters, the students suggest that classroom materials should include those related to communication and information technologies. They also mention the importance of carrying out immersion sessions with native speakers to develop oral skills, to be exposed to standardized tests, and get some instruction on learning strategies to promote autonomy and independence (Allwright, 1990, and Little, 1991, as cited in Oxford, 2001). Regarding immersion sessions, students made comments, as the following, in the survey carried out by the Professional Practice Committee:

- S1: "[...] more spaces for interaction [...] should be provided, and even if the hours per week for English and French classes are reduced." [sic]

- S2: "[...] that the students be exposed to the foreign language much longer than they are and that the teachers use the $\mathrm{L} 2$ more so that we can interact more with them." [sic]

- S3: "More immersion activities and [...] more class hours with native teachers, since in some semesters we don't even have a couple of hours with a native teacher, this for both languages, since there has always been more inclination for English.” [sic]

- S4: "Have more [learning] spaces where I can express myself, that teachers demand much more the language use both inside and outside the class and that within classes more activities focused on this ability be carried out." [sic]

Basic standards on foreign language competences: English. 
As for the first questionnaire, 108 students participated; although not all of them answered the 63 questions contained in it. Results show that the most common reasons for studying modern languages are interest in the foreign languages, traveling, being a teacher, being an interpreter, and working overseas. Only 27 out of 108 students are interested in being teachers, despite studying for a bachelor's degree, as shown in Figure 1 below.

\section{I study modern languages because:}

108 responses

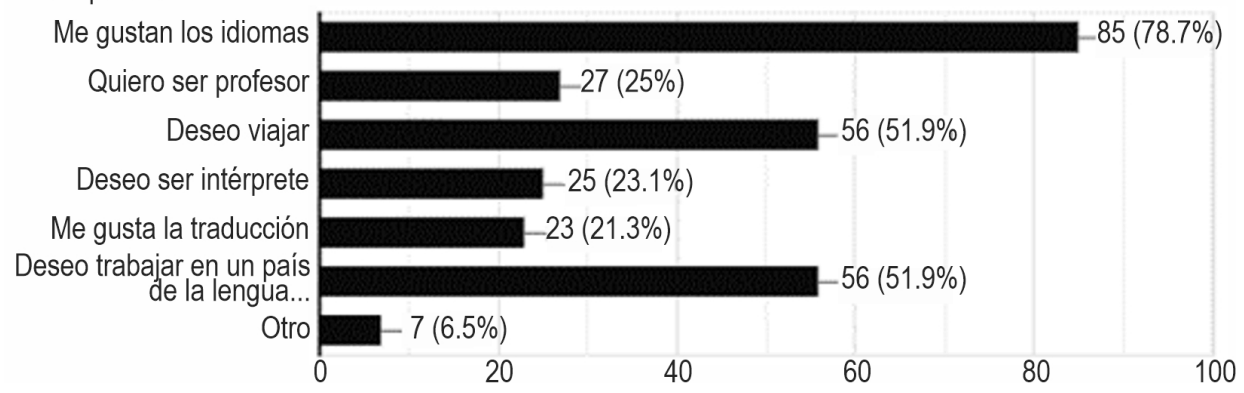

Figure 1. Students' Reasons to Study Modern Languages

Results also show that students' expectations concerning language instruction would suggest work more focused on content rather than linguistic aspects. Between $50 \%$ and $60 \%$ of the students expect to be able to understand content, courses, talks, dialogues, songs, radio programs, to do and understand presentations, ask, and answer questions, do assignments, write dictations, read literary works, and write summaries. Only $33.3 \%$ of 107 students answered that they would like to learn languages to teach, whereas $35.5 \%$ expect to use it to interact in the target culture, and $25.2 \%$ as professional support. Students' expectations are related to being able to use L2 in context, having the ability to use L2 to interact, certify language level and develop argumentative competence.

In the first questionnaire, students were given a list of expectations about their performance in both oral and written competences, with two options that would show students' level of expectation in those competences, which were quite well (from 50\% to $80 \%$ of achievement) and very well (more than $80 \%$ of achievement) (see Annex 1). The percentages obtained in each option were added and divided into the number of expectations to estimate the mean for each option. Results showed that $58.84 \%$ of the students would like to perform quite well and $41.16 \%$ very well in the competences given in the list. The highest percentages range from $63 \%$ to $76 \%$ of students who would like to perform quite well when they respond to an interview, correct English written by others, read research articles, write 
critical comments, defend, or dispute opinions, and participate in debates and seminars. The following Figures 2 to 7 display this information.

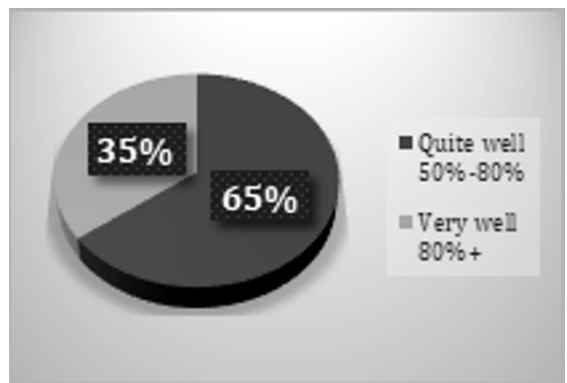

Figure 2. Respond to an Interview

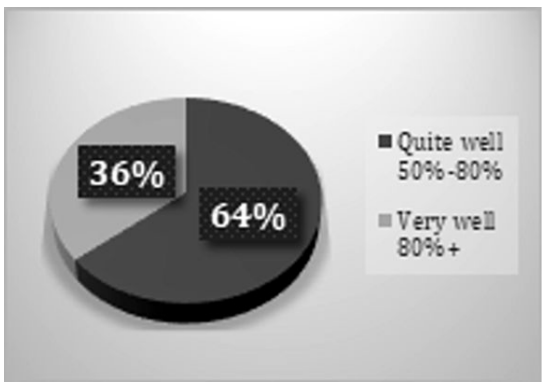

Figure 4. Read Research Articles

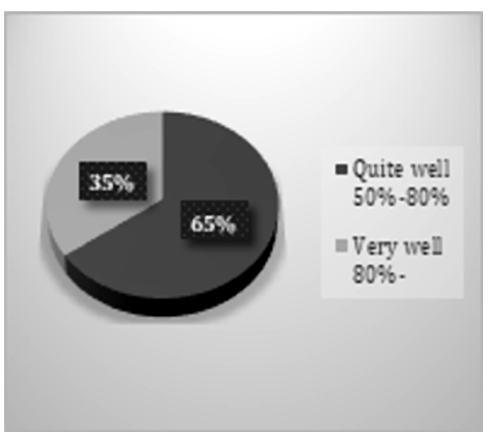

Figure 6. Defend/Dispute Opinions

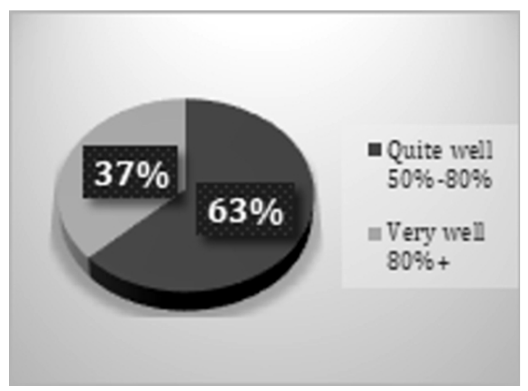

Figure 3. Correct English

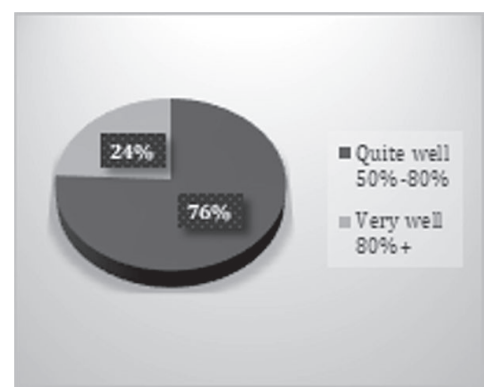

Figure 5. Write Critical Comments

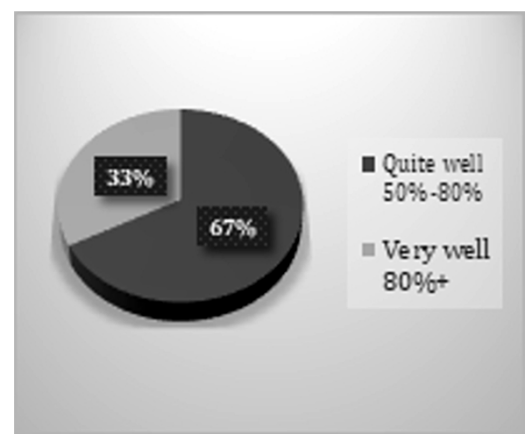

Figure 7. Participate in Debates and Seminars 
As for students' general learning expectations, the first question was about the use they expect to give to the target language by the end of the major. Figure 8 shows that the highest percentage corresponds to interacting in the target culture, followed by teaching, and supporting a profession other than teaching. Figure 9 shows the results obtained for the language level that students expect to achieve by the end of the degree, and Figure 10 shows that most of the students expect to certify their level of proficiency through a standardized test.

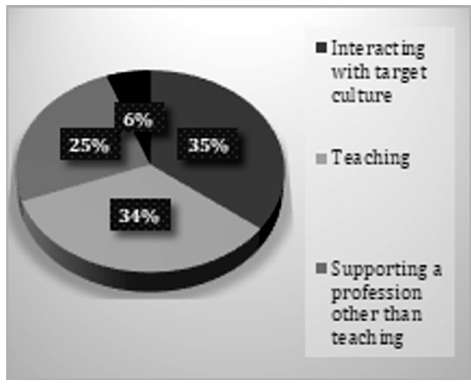

Figure 8. Use of Target Language

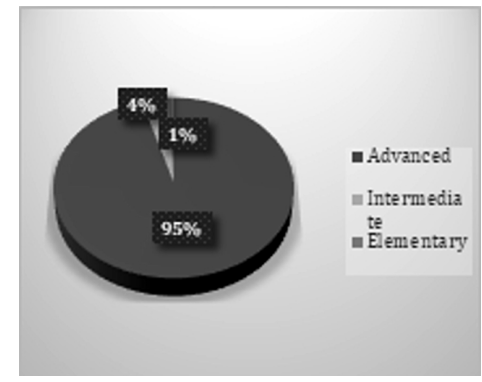

Figure 9. Language Level Achievement

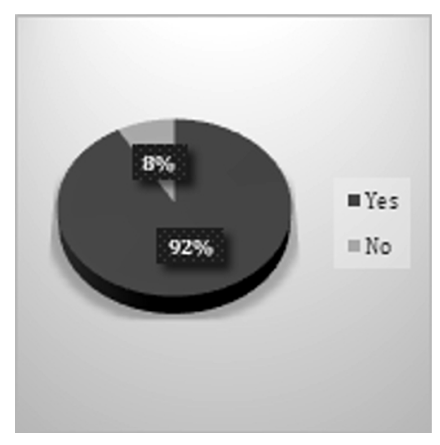

Figure 10. Certify Proficiency Level

In addition, students referred to their learning needs to develop language skills. For instance, to develop oral expression, they need to overcome the fear of making mistakes and have greater exposure to L2 with greater accompaniment of native teachers. To develop oral comprehension, they need to be more disciplined and committed, do peer work, and use listening strategies. To develop reading comprehension, they require instruction in 
strategies and be exposed to different types of texts. Finally, writing can be developed by using strategies.

Table 2 below shows each of the options about the use of the learning strategies. Tables 3, 4, 5, 6, and 7 below show the results of the survey devoted to general learning strategies used for listening, vocabulary, speaking, reading, writing, and translation, and some suggestions for the program.

Table 2. First Questionnaire. Rubric for the Use of Learning Strategies

\begin{tabular}{|l|l|}
\hline \multicolumn{1}{|c|}{ Use of strategies } & Options \\
\hline I have used this strategy and I like it & Option 1 \\
\hline I have tried to use this strategy and I use it again & Option 2 \\
\hline I have never used this strategy, but I am interested in it & Option 3 \\
\hline This strategy does not catch my attention & Option 4 \\
\hline
\end{tabular}

Table 3. Strategies Used to Learn Vocabulary

\begin{tabular}{|l|c|c|c|c|}
\hline \multicolumn{1}{|c|}{ Vocabulary } & $\begin{array}{c}\text { O1 } \\
\text { \% }\end{array}$ & $\begin{array}{c}\text { O2 } \\
\text { \% }\end{array}$ & $\begin{array}{c}\text { O3 } \\
\text { \% }\end{array}$ & $\begin{array}{c}\text { O4 } \\
\text { \% }\end{array}$ \\
\hline Strategies to learn new words & 54.4 & 36.9 & 5.8 & 2.9 \\
\hline Strategies to review vocabulary & 33 & 46.6 & 16.5 & 3.9 \\
\hline Strategies to remember vocabulary & 37.9 & 44.7 & 16.5 & 1 \\
\hline Strategies to use new vocabulary & 47.6 & 35 & 17.5 & \\
\hline
\end{tabular}

Table 4. trategies Used for Speaking

\begin{tabular}{|l|c|c|c|c|}
\hline \multicolumn{1}{|c|}{ Speaking } & $\begin{array}{c}\text { O1 } \\
\text { \% }\end{array}$ & $\begin{array}{c}\text { O2 } \\
\text { \% }\end{array}$ & $\begin{array}{c}\text { O3 } \\
\text { \% }\end{array}$ & $\begin{array}{c}\text { O4 } \\
\text { \% }\end{array}$ \\
\hline Strategies to practice speaking & 51.5 & 36.9 & 11.7 & \\
\hline Strategies to get involved in a conversation & 35.9 & 43.7 & 19.4 & 1 \\
\hline $\begin{array}{l}\text { Strategies for when I cannot think } \\
\text { of a word or expression }\end{array}$ & 40.8 & 44.7 & 12.6 & 1.9 \\
\hline
\end{tabular}


Table 5. Strategies Used for Reading

\begin{tabular}{|l|c|c|c|c|}
\hline \multicolumn{1}{|c|}{ Reading } & $\begin{array}{c}\text { O1 } \\
\text { \% }\end{array}$ & $\begin{array}{c}\text { O2 } \\
\text { \% }\end{array}$ & $\begin{array}{c}\text { O3 } \\
\mathbf{\%}\end{array}$ & $\begin{array}{c}\text { O4 } \\
\mathbf{\%}\end{array}$ \\
\hline Strategies to improve reading skills & 47.6 & 37.9 & 14.6 & 15 \\
\hline $\begin{array}{l}\text { Strategies for when words and grammar } \\
\text { structures cannot be understood }\end{array}$ & 40.8 & 41.7 & 17.5 & 18 \\
\hline
\end{tabular}

Table 6. Strategies Used for Writing

\begin{tabular}{|l|c|c|c|c|}
\hline \multicolumn{1}{|c|}{ Writing } & $\begin{array}{c}\text { O1 } \\
\text { \% }\end{array}$ & $\begin{array}{c}\text { O2 } \\
\text { \% }\end{array}$ & $\begin{array}{c}\text { O3 } \\
\text { \% }\end{array}$ & $\begin{array}{c}\text { O4 } \\
\text { \% }\end{array}$ \\
\hline Strategies for basic writing & 52.4 & 35 & 9.7 & 2.9 \\
\hline $\begin{array}{l}\text { Strategies to write an essay } \\
\text { or an academic report }\end{array}$ & 30.4 & 42.2 & 22.5 & 4.9 \\
\hline $\begin{array}{l}\text { Strategies to use after writing } \\
\text { a draft of an essay or report }\end{array}$ & 31.1 & 41.7 & 25.2 & 1.9 \\
\hline
\end{tabular}

Table 7. Strategies Used for Translation

\begin{tabular}{|l|c|c|c|c|}
\hline \multicolumn{1}{|c|}{ Translation } & $\begin{array}{c}\text { O1 } \\
\mathbf{\%}\end{array}$ & $\begin{array}{c}\text { O2 } \\
\mathbf{\%}\end{array}$ & $\begin{array}{c}\text { O3 } \\
\mathbf{\%}\end{array}$ & $\begin{array}{c}\text { O4 } \\
\mathbf{\%}\end{array}$ \\
\hline Strategies for translation & 52.4 & 35 & 9.7 & 2.9 \\
\hline $\begin{array}{l}\text { Strategies to work directly } \\
\text { in the target language }\end{array}$ & 30.4 & 42.2 & 22.5 & 4.9 \\
\hline
\end{tabular}

The following are sample comments on students' learning strategies:

- S5: "The implementation of conversation clubs in the program is an idea that cannot be discarded, it is an opportunity for students to put into practice what they have seen in class, learning and teaching cannot be limited to the classroom or virtual resources [...]" [sic]

- S6: "Because the reading of texts is progressing little by little and also in the level of difficulty of these with specific topics, for me it would be ideal to review types of expressions and specific vocabulary related to the topic of the text to be read to contextualize the students." [sic] 
- S7: “[...] not only accept academic writings as grades or assignments, there are many types of writings that have more influence or interest for students." [sic]

Findings emerging from this section of the survey show that students need instruction in the use of learning strategies in all the language skills. Regarding listening, they need guidelines to carry out listening exercises and strategies to prepare to listen to and to analyze oral discourse. As for vocabulary, they need strategies to learn lexicon, memorize it and use it in context. Regarding speaking, they need to develop communication strategies. To develop reading and writing, they need to have command of complex grammar to understand and produce academic texts and strategies for editing texts. Translation is not emphasized in the program; however, students would mainly resort to Spanish to carry out reading and writing comprehension exercises.

The second questionnaire focused on the students' standards of competences. The data from the closed questions were analyzed according to the mean derived from the percentages obtained in each skill. This questionnaire aimed to explore both strengths and weaknesses with respect to the students' communicative competences in comparison to the standards defined for each semester and then to identify students' learning needs in all the language skills. In addition, students' comments on their learning process, resulting from the openended questions, were categorized into groups according to common aspects which led to drawing conclusions as to how they see the development of their competences and the greater needs they are facing to achieve it. Table 8 below shows in percentages, the standards of competences achieved by the students in all of the semesters, both in English and French.

Table 8. Second Questionnaire. Standards of Competences

\begin{tabular}{|l|c|c|c|c|c|c|c|c|c|c|}
\hline \multicolumn{1}{|c|}{$\begin{array}{c}\mathbf{N}^{\circ} \text { of } \\
\text { students } \\
\text { per } \\
\text { Semester }\end{array}$} & \multicolumn{2}{|c|}{ Listening } & \multicolumn{2}{c|}{ Reading } & \multicolumn{2}{c|}{ Conversation } & \multicolumn{2}{c|}{ Speaking } & \multicolumn{2}{c|}{ Writing } \\
\cline { 2 - 11 } & Op. 1 & Op. 2 & Op 1 & Op. 2 & Op. 1 & Op. 2 & Op.1 & Op. 2 & Op. 1 & Op.2 \\
\hline $\begin{array}{l}\text { I (8)- } \\
\text { II (19)- }\end{array}$ & 93.65 & 6.35 & 74.73 & 25.27 & 75.45 & 24.55 & 88.78 & 11.22 & 80.95 & 19.05 \\
\hline $\begin{array}{l}\text { III (23) } \\
\text { IV (1) }\end{array}$ & 83.31 & 16.69 & 81.25 & 18.75 & 69.04 & 30.95 & 66.66 & 33.33 & 60.95 & 39.05 \\
\hline $\begin{array}{l}\text { V (15) } \\
\text { VII (24) }\end{array}$ & 66.23 & 33.76 & 61.50 & 38.49 & 75.3 & 24.3 & 65.03 & 34.96 & 68.52 & 31.47 \\
\hline $\begin{array}{l}\text { IX (11) } \\
\text { X (7) }\end{array}$ & 46.43 & 53.56 & 68.35 & 31.64 & 55.35 & 44.65 & 61.02 & 38.97 & 66.32 & 33.67 \\
\hline
\end{tabular}


The highest percentages are in option 1, which refers to what the students can do, and the lowest ones, to what they cannot do, but they find necessary in all language skills.

Going deeper into specific competences of the students in first and second semesters, it was found that strategies to get the main idea of an audio recording are needed, as well as strategies to understand a story plot, identify the most important episodes, and get the main idea of reading texts. Also, a number of students cannot write informal messages between friends, use situational language for shopping, exchange money, ask for directions, describe past events, and start a conversation. In written skills, several students cannot narrate an event with simple phrases, fill out a form with personal information, write about everyday life, or write an informal letter.

According to the findings, the students from second semester need to address topics or to be exposed to material that allows them to rehearse everyday life situations. This would promote meaningful learning and would allow them to develop communicative competences according to the standards defined for elementary level.

As for the open-ended questions, answers focused on linguistic knowledge and the target culture, fear of public speaking, French pronunciation, exposure to L2, listening skill material, and face-to-face classes.

Regarding students in third and fourth semesters, there is a need to be exposed to authentic material and literary texts to reinforce strategies to express opinions on a given topic, to create spaces for interaction, to describe feelings, argue, follow directions, explain a topic, and receive feedback on their performance. Furthermore, various students cannot write a press release or a short article for a school magazine, nor can they write the summary of a curriculum vitae or describe it in a personal letter, or of a plot from a movie or book.

For the development of competences, the students find it necessary to reinforce writing and grammar in French, to be more exposed to input in English and French that helps them develop oral fluency, and to sustain a conversation. There is also a necessity to have more class hours of English and French, especially in the new curriculum, be exposed to different forms of learning, reinforce phonetics and vocabulary, engage in interaction spaces, develop more autonomous work, and provide more interest in listening skills.

With respect to fifth and sixth semesters, it was found that students do not have much difficulty understanding standard language in both listening and reading. However, when it comes to getting the main idea of a complex discourse related even to familiar topics, most students express lack of strategies to do so. In the data that emerged from the documentary analysis and the survey, students expressed the need to be exposed to L2 in activities that generate interaction in all subjects. This could help them become familiar with technical language and be able to participate in extensive conversations and discussions on topics of general interest. 
The balance leans more towards what students can do regarding writing ability, except for two specific competences: writing essays and highlighting decisive points and support.

Regarding the open question, students identified as their greatest needs 1) to learn vocabulary and develop fluency in oral expression, 2) work on learning strategies in both languages, 3) reinforce L2 use, 4) feel comfortable with themselves and their process, 5) be involved in immersion activities, 6) have a language laboratory, and 7) increase motivation towards learning. Based on these findings, students' language competences seem to be related to evaluation processes which might not be aligned with the standards required at that level. Therefore, the undergraduate program needs to revise the criteria to promote students. For instance, two students commented:

- S8: "“. $[\ldots]$ More demand is lacking, $[\ldots]$ a balance between demanding $[\ldots]$ but with a good motivation of the students." [sic]

- S9: "I feel necessary to be at a higher level of immersion in English." [sic]

Finally, as for students in ninth and tenth semesters, the results show that the greatest needs for developing competences lie in putting ideas in writing, the lack of external motivation, autonomy, more support from teachers, interaction spaces, and reflective language practice. The following are two students' comments with respect to this:

- S10: "I consider that my greatest need is to have more spaces where I can practice all the skills $[\ldots]$ and in the city, French is not very common for people to speak this language [French]." [sic]

- S11: "My greatest need would be to have more spaces not only autonomous but also in support with the teachers of the program to read in the other language and to interact in real more than created situations." [sic]

\section{Conclusions}

After analyzing the data and taking into account the findings emerging from the research that aimed to analyze the learning needs of Modern Languages students at the University of Cauca, I feel the following conclusions can be stated:

30 Autonomy plays an important role in language learning as it implies being exposed to the target language as much as possible. Nevertheless, it was found in the documentary analysis and other data collection instruments that students are aware of their lack of autonomy, commitment, responsibility, and motivation towards learning; this awareness becomes one of the main hindrances in their learning and language performance.

Instruction in learning strategies is meant to promote learner autonomy and to develop meaningful learning; thus, when this kind of instruction is not a fundamental aspect in 
curriculum design, students do not make the most of learning and their progress can take longer than expected.

Most students participating in the study do not aim to be teachers but to work in other fields in which the foreign language can be used to communicate and interact in different contexts. Anyway, since it is known that there is a high demand of language teachers in the region, mainly English, students might consider working as teachers as a secondary choice just in case they do not find other job opportunities.

The curriculum of the program proposes the development of communication skills being encouraged according to the standards established by the Ministry of National Education for the bachelor's degree programs in Colombia; however, it was found that students require more exigence from the program in the development of communicative competences to achieve the required standards.

In a context like Colombia, foreign language learning is meant to be intervened by teachers who are called upon to be input providers as one of their most important roles.

Even though diagnostic tests are implemented in the language program to identify students' level and plan regarding the teaching actions, according to the research findings, students from elementary levels expressed the need of being provided with more comprehensible input that allows them to develop language skills progressively and effectively.

The need of immersion spaces in the target languages is the most mentioned by students. The reasons they express are that these activities promote interaction in an anxietyfree environment, language can be used freely in real life situations, fluency takes on more importance than accuracy, and interaction is promoted.

Teaching and learning imply a permanent interaction among the parties involved, that is, teachers and students. Therefore, establishing a good rapport contributes significantly to this process, since in most cases students feel afraid of speaking or asking questions of the teachers or other classmates because they do not want to be on the spot or judged if they make mistakes.

As part of teaching methodologies, grading materials facilitate learning. Students from different semesters agree on the fact that most of these are not innovative, which in many cases turn classroom activities monotonous, thus affecting their motivation and interest. The lack of resources aligned with communication and information technologies in the program has become a hindrance in addressing students' learning styles.

Exposure to the target language in subjects other than English and French allows students not only to become familiar with technical language, but also to improve their 
motivation towards learning as they deal with content related to different knowledge areas of the curriculum.

Considering that being a teacher is not an expectation of most of the population, I would say that this aspect is a determining factor in the level of interest and commitment to learning if languages are taught only to pursue teaching, overlooking the target culture. One of the students' learning needs is to be exposed to materials and participate in activities and programs whereupon they can learn about French and English cultures.

\section{References}

Arismendi, F., \& Colorado, D. (2015). La formation des enseignants de FLE en Colombie: Panorama et cas de l'Université d'Antioquia. http:// hdl.handle.net/10495/16657

Ayala, J., \& Álvarez, J. (2005). A perspective of the implications of the common European framework implementation in the Colombian socio-cultural context. Colombian Applied Linguistics Journal, 7. https://revistas.udistrital.edu.co/index.php/calj/article/view/162/260

Bailey, A. (2017). Necesidades y percepciones en el aprendizaje del inglés como lengua extranjera. IKALA, 22(3), 501-516.

Bedoya, P., et al. (2015). Students' needs analysis in an EFL program for university professors. HOW, 22(2), 11-36.

British Council (2015). English in Colombia: An examination of policy, perceptions and influencing factors in Colombia. https://www.teachingenglish.org.uk/sites/teacheng/files/English $\% 20$ in $\% 20$ Colombia.pdf

Brown, D. (2007). Principles of language learning and teaching. Longman and Pearson Education.

Cárdenas, R., et al. (2015). Implementación del programa nacional de bilingüismo Cali-Colombia. Universidad del Valle Programa Editorial.

Cartier, S. (2000). Enseigner les stratégies d'apprentissage aux élèves du collégial pour que leur français se porte mieux. Métacognition, 5(3).

Cohen, A., et al. (1990). Language strategy use inventory. https://carla.umn.edu/maxsa/documents/LanguageStrategyInventory_MAXSA.pdf

Common European Framework for Languages (2001). Language, teaching, assessment. https://rm.coe.int/common-european-framework-of-reference-for-languages-learningteaching/16809ea0d4

Dornyei, Z. (2001). Motivational strategies in the language classroom. Cambridge University Press.

Duquette, L. (2002). Analyse de données en apprentissage d'une L2 en situation d'autonomie dans un environnement multimédia. Alsic [En ligne], 5(1).

Escorcia, B., et al. (1995). Learning to teach, teaching to learn: COFE Project. UK.

Gómez, M. (2017). Review and analysis of the Colombian foreign language bilingualism policies and plans. HOW, 24(1), 139-156. 
Groux, D., et al. (2003). Pour un apprentissage précoce des langues. Le Français Dans Le Monde, 330, 23-33.

Harmer, J. (2007). How to teach English. Pearson Education Limited.

Jiménez, P. (2018). Exploring students' perceptions about English learning in a public university. HOW, 25(1), 69-91. https://doi.org/10.19183/how.25.1.385.

Lightbown, P., \& Spada, N. (1999). How languages are learned. Oxford Handbooks for Language Teachers. Oxford University Press.

Little, D., \& Perclová, R. (2001). The European Language Portfolio: A guide for teachers and teacher trainers. https://rm.coe.int/1680459fa6

Ministerio de Educación Nacional (1994). Ley General de Educación. (Ley 115 del 8 de febrero de 1994). https://www.mineducacion.gov.co/1621/articles-85906_archivo_pdf.pdf

Ministerio de Educación Nacional (2004). Programa nacional de bilingüismo 2004-2019.

https://www.mineducacion.gov.co/1621/articles-132560_recurso_pdf_programa_nacional_bilinguismo.pdf

Ministerio de Educación Nacional (2006). Estándares básicos de competencias en lenguas extranjeras: inglés. Formar en lenguas extranjeras: el reto. https://www.mineducacion.gov. co/1621/articles-115174_archivo_pdf.pdf

Ministerio de Educación Nacional (2010). Proyecto de fortalecimiento al desarrollo de competencias en lenguas extranjeras. https://www.mineducacion.gov.co/1759/articles-327001_archivo_pdf_terminos_convocatoria.pdf

Ministerio de Educación Nacional (2018). Programa nacional de bilinguismo 2018-2022.

http://aprende.colombiaaprende.edu.co/es/colombiabilingue/86718

Mohammed, E., \& Mohammed, S. (2018). Needs analysis in English for academic purposes: The case of teaching assistants at the University of Khartoum. HOW, 25(2), 49-68.

Moreno, A. (2004). Análisis de necesidades para el aula de lengua inglesa en filología inglesa. Un estudio de caso. Dpto. de Filología Moderna. Universidad de Barcelona. https://core.ac.uk/download/ pdf/39074397.pdf

Oxford, R. (2001). Language learning styles and strategies: An overview.

Pérez, N. (2018). L'education interculturelle en FLE selon les specificités socioculturelles despays d'Amérique du Sud: le cas de la Colombie. In C. Eid et al. (Eds.), Francais langue ardante (pp. 323-330). Fédération Internationale des Professeurs De Francais.

Proyecto Educativo del Programa (2017). Programa de Lenguas Modernas con Énfasis en Inglés y francés. Universidad del Cauca.

Ramos-Holguín, B. (2021). Comprehending interculturality and its future directions in English language teaching and teacher education in the Colombian context. HOW, 28(3), 93-104. https://doi.org/10.19183/how.28.3.674. 
Redacción vida hoy/Educación. (2017, March 25). El fránces se posiciona como tercer idioma para los colombianos. El Tiempo. https://www.eltiempo.com/vida/educacion/aprenderfrances-en-colombia-71198

Resolución 12730 [Ministerio de Educación Nacional]. Por la cual se publica la lista de exámenes estandarizados para la certificación del nivel de dominio lingüístico y se dictan otras disposiciones. 28 de junio de 2017.

Resolución 18583 [Ministerio de Educación Nacional]. Por la cual se ajustan las características específicas de calidad de los programas de Licenciatura para la obtención, renovación o modificación del registro calificado, y se deroga la Resolución 2041 de 2016. 15 de septiembre de 2017. http://legal.legis.com.co/document/Index?obra=legcol\&document=legcol_00821d7db80a4391b82274489461d53b

Robert, J., et al. (2011). Faire classe en FLE: Une approche actionnelle et pragmatique. Hachette français langue étrangère.

Sánchez, A., \& Obando, G. (2008). Is Colombia ready for "bilingualism"? Profile Issues in Teachers ' Professional Development, 9, 181-196.

Torres-Martínez, S. (2009). Las vicisitudes de la enseñanza de lenguas en Colombia. Diálogos Latinoamericanos, 15.

Usma, J. (2009). Education and language policy in Colombia: Exploring processes of inclusion, exclusion, and stratification in times of global reform. Profile: Issues in Teachers' Professional Development, 11, 123-141.

Wallace, M. (1998). Action research for language teachers. Cambridge University Press. 


\section{Annex.}

\section{Students' learning expectations regarding their performance in both oral and written competences.}

\begin{tabular}{|c|c|c|}
\hline $\begin{array}{l}\text { DCCO: Desempeño en las competencias } \\
\text { comunicativas orales } \\
\text { DCCE: Desempeño en las competencias } \\
\text { comunicativas escritas } \\
\text { EGA: Expectativas generales de aprendizaje }\end{array}$ & $\begin{array}{l}\text { Opción } 1 \\
\text { Bastante } \\
50 \%-80 \%\end{array}$ & $\begin{array}{c}\text { Opción } 2 \\
\text { Mucho + } \\
\text { del } 80 \%\end{array}$ \\
\hline $\begin{array}{l}\text { 22. (DCCO) Entender el contenido de } \\
\text { cursos, clases, charlas o conferencias. }\end{array}$ & 50.9 & $49.1 \%$ \\
\hline $\begin{array}{l}\text { 23. (DCCO) Mantener conversaciones } \\
\text { formales e informales }\end{array}$ & 62 & $38 \%$ \\
\hline $\begin{array}{l}\text { 24. (DCCO) Responder } \\
\text { adecuadamente una entrevista }\end{array}$ & 63 & $37 \%$ \\
\hline $\begin{array}{l}\text { 25. (DCCO) Entender diálogos de películas, letras } \\
\text { de canciones y programas de radio y televisión }\end{array}$ & 57.4 & $42.6 \%$ \\
\hline 26. (DCCO) Hacer y entender presentaciones orales & 57.4 & $42.6 \%$ \\
\hline 27. (DCCO) Atender a un visitante o ser atendido & 59.8 & $40.2 \%$ \\
\hline 28. (DCCO) Hacer y responder preguntas en clase & 56.1 & $43.9 \%$ \\
\hline 29. (DCCO) Participar en debates y seminarios & 75.7 & $24.3 \%$ \\
\hline 30.(DCCO) Defender o rebatir opiniones & 67.3 & $32.7 \%$ \\
\hline $\begin{array}{l}\text { 31. (DCCO) Hablar sobre las causas y } \\
\text { consecuencias de determinados hechos }\end{array}$ & 64.3 & $35.8 \%$ \\
\hline 32. (DCCE) Hacer traducciones & 56.7 & $43.3 \%$ \\
\hline $\begin{array}{l}\text { 33. (DCCE) Redactar trabajos para } \\
\text { entregar a los profesores. }\end{array}$ & 55.1 & $44.9 \%$ \\
\hline 34. (DCCE) Leer artículos de investigación & 64.8 & $35.2 \%$ \\
\hline 35. (DCCE) Corregir el inglés escrito por otros & 64.2 & $35.8 \%$ \\
\hline 36. (DCCE) Escribir comentarios críticos & 65.1 & $34.9 \%$ \\
\hline 37. (DCCE) Escribir dictados & 53.3 & $46.7 \%$ \\
\hline 38. (DCCE) Leer libros de texto & 44.9 & $55.1 \%$ \\
\hline $\begin{array}{l}\text { 39. (DCCE) Escribir cartas de solicitud } \\
\text { de empleo y curriculum vitae }\end{array}$ & 60.2 & $39.8 \%$ \\
\hline 40. (DCCE) Leer obras literarias & 56.6 & $43.4 \%$ \\
\hline
\end{tabular}




\begin{tabular}{|c|c|c|}
\hline $\begin{array}{c}\text { DCCO: Desempeño en las competencias } \\
\text { comunicativas orales } \\
\text { DCCE: Desempeño en las competencias } \\
\text { comunicativas escritas } \\
\text { EGA: Expectativas generales de aprendizaje }\end{array}$ & $\begin{array}{l}\text { Opción } 1 \\
\text { Bastante } \\
50 \%-80 \%\end{array}$ & $\begin{array}{l}\text { Opción } 2 \\
\text { Mucho }+ \\
\text { del } 80 \%\end{array}$ \\
\hline $\begin{array}{l}\text { 41. (DCCE) Leer y escribir correspondencia } \\
\text { (correo ordinario, fax y correo electrónico }\end{array}$ & $54.7 \%$ & $45.3 \%$ \\
\hline 42. (DCCE) Leer la prensa & $62.7 \%$ & $37.3 \%$ \\
\hline 43. (DCCE) Escribir resúmenes & $52.8 \%$ & $47.2 \%$ \\
\hline 44. (DCCE) Tomar apuntes & $48.6 \%$ & $51.4 \%$ \\
\hline \multirow{4}{*}{$\begin{array}{l}\text { 45. (EGA) Cuál es el uso que espera darle a la L2 } \\
\text { objeto de aprendizaje al terminar la carrera? }\end{array}$} & Docencia & $33.6 \%$ \\
\hline & Interacción cultura objeto & $35.5 \%$ \\
\hline & Apoyo profesional & $25.2 \%$ \\
\hline & Otro & $5.6 \%$ \\
\hline \multirow{3}{*}{$\begin{array}{l}\text { 46. (EGA) Cuál es el nivel de lengua que } \\
\text { espera alcanzar al terminar la carrera? }\end{array}$} & Elemental & $0.9 \%$ \\
\hline & Intermedio & $3.7 \%$ \\
\hline & Avanzado & $95.3 \%$ \\
\hline \multirow{2}{*}{$\begin{array}{l}\text { 47. (EGA) Espera certificar su nivel } \\
\text { de lengua mediante una prueba } \\
\text { estandarizada al terminar la carrera? }\end{array}$} & Sí & $91.6 \%$ \\
\hline & No & $8.4 \%$ \\
\hline \multirow{3}{*}{$\begin{array}{l}\text { 49. (EGA) Desea aplicar a una } \\
\text { beca al terminar la carrera? }\end{array}$} & Sí & $51.9 \%$ \\
\hline & No & $7.4 \%$ \\
\hline & Tal vez & $40.7 \%$ \\
\hline
\end{tabular}

Note: Adapted from Moreno, A. (2004). Análisis de necesidades para el aula de lengua inglesa en filología inglesa: Un estudio de caso. Dpto. de Filología Moderna. Universidad de Barcelona. https://core.ac.uk/download/ pdf/39074397.pdf 